\title{
Precedent Names in the Text Field of Marina Tsvetaeva from the Perspective of Free Indirect Discourse
}

\author{
Daniya Abuzarovna Salimova ${ }^{1}, \&$ Olga Pavlovna Puchinina ${ }^{1}$ \\ ${ }^{1}$ Elabuga Institute (Branch) of Kazan Federal University, Russia \\ Correspondence: Olga Pavlovna Puchinina, Elabuga Institute (Branch) of Kazan Federal University, 20 A, \\ Gassara Street, Flat 99, Elabuga, 423600, Russia. E-mail: olga.puchinina@gmail.com
}

Received: May 1, 2017

doi:10.5539/ass.v13n7p142
Accepted: May 26, $2017 \quad$ Online Published: June 23, 2017

URL: https://doi.org/10.5539/ass.v13n7p142

\begin{abstract}
The present study is complied with the topical theme "name in the text" and devoted to the problems of how precedent names as the text-forming elements function in the poems and prose works of Marina Tsvetaeva within the framework of free indirect discourse. The authors study various methods and functions of personal names. The authors make conclusions concerning the frequency of precedent names and the specific character of intertextual elements in Tsvetaeva's text, which, on the one hand, complicates the perception of the text, but on the other hand, promotes including both the poet and the reader into the world-wide cultural and spiritual environment. The ways of introducing the name and the persona, especially within free indirect discourse, specifies the further existence of the name / or its absence in the text.
\end{abstract}

Keywords: text, anthroponyms, free indirect discourse, language game, precedent names.

\section{Introduction}

The purpose of this article is to describe one specific segment (anthroponyms as precedent names) of the great poet's texts in terms of their use in a text space - namely, the ways and means of introducing personal names in the structure of free indirect discourse (FID). The study is based on several collections of Marina Tsvetaeva's poetic and prosaic works (poems, letters, stories, novels, diaries), which make the abundant material for linguistic stylistics. In general, we have analyzed more than 500 personal names, continuously sampled, used in various positions in the text and functions. Besides, our intention was not to investigate only one period in the poet's work or a particular thematic cycle, because we are interested in the way the poet uses precedent names throughout all the stages of her creative work.

\section{Discussion}

The language and individual style of Marina Tsvetaeva are one of the most popular and relevant philological spheres in the past decades. We wrote, "In our opinion there is a certain "Tsvetaeva fashion" among linguists now. The rhythm, color, punctuation, concepts of her poems are just a few topics, related to the texts of Marina Tsvetaeva, which have been studied most of all" (Salimova and Danilova, 2009). Thus, there are no grounds to consider the poet's linguostylistics underinvestigated. However, Tsvetaeva's poetry and prose are so mysterious that any study can fill a gap in Tsvetaeva's vast and infinite text field.

The Tsvetaeva readings, conducted in Elabuga Institute of Kazan Federal University every two years, as well as a great number of original and significant research in Russia and around the world testify to the enduring interest of readers and specialists in different areas to Marina Tsvetaeva's creative work, including the poet's style, and to her onomastics, in particular. Among the research, dedicated to the onomastic (chiefly, toponymic) layer of Tsvetaeva's texts, it's necessary to mention such works as "Proper names in the poetic individual style of Marina Tsvetaeva" by O. G. Revzina (1991), "Onomastics in fiction: Philological studies” by M. V. Gorbanevskiy (1988) and others.

A number of facts motivate the problems of this study and its relevance. Firstly, we aim to study the "behavior" of the name in the text in a completely new perspective; secondly, the precedence, intertextuality, of the poet's texts is viewed not only as the involvement of Tsvetaeva into the world cultural space, but also as the expression of the author's pragmatism, aimed at an educated reader. We hope that our material will contribute to revealing one of the characteristic features of Marina Tsvetaeva's style, which can't make students indifferent to it; but, in 
many respects, the poet remains a secret not only for schoolchildren, but also for specialists.

In this article, we examine the precedent names in the structure of FID, considered by many scientists a special kind of rendering another person's speech, which has a particular linguistic potential. The theoretical interest to FID has been reflected in philological science since the first observations by A. Tobler, P. Kozlovskiy, Ch. Bally. This undying interest can be attributed to the inexhaustible artistic and aesthetic potential of FID in the world literature (Kusjko, 1980).

Among many concepts of FID, we single out the following ones: 1) In 1887, the first researcher of FID A. Tobler viewed it as a mixture of direct and indirect speech. This idea of "mixing" became the basis of the latest concepts of FID. 2) The representatives of the Geneva School of Charles Bally interpreted it as a modification of the indirect speech. Ch. Bally wrote that FID (Le style indirect libre in his terminology) is an objective and purely literary phenomenon and grammatically static (Bally, 1912). 3) G. Lerch and his followers treat FID as a modification of direct speech, or as a way of its representation in the author's narrative structure. 4) The majority of Russian and foreign researchers of FID (T. Kalepki, E. Lerch, E. Lorck, etc.) consider it an individual form of rendering of somebody's utterance.

In addition, T. Kalepky and E. Lerch considered FID from a psychological point of view. For example, Kalepky insisted that the narrator was not a simple carrier of a character's voice, as Ch. Bally put it. It is a subject, thus, the utterance itself is not objective, but subjective (Kalepky, 1913). The German linguist E. Lerch was interested in the stylistic potential of the device. In the article "Die stilistische Bedeutung des Imperfektums der Rede "style indirect libre" ("The stylistic meaning of FID") he writes that FID can act as something similar to both direct and indirect speech (Lerch, 1914).

Russian linguistics also contributed to the study of the phenomenon. For instance, an outstanding Russian linguist M. M. Bakhtin described FID as a special device to introduce someone else's consciousness in dramatic epic (novel), besides, he used the term "reflected word of another person". He noted that various combinations of the three syntactic speech patterns (direct speech, indirect speech and FID) and diverse ways of framing and intercalating them with the author's context contribute to a diverse game of speeches, their mutual over-splashing and responsive infection (Bakhtin, 1975).

O. A. Blinova notes the pragmatic focus of modern theories concerning FID, which are based on the work of the Austrian linguist M. Fludernik. She states that only pragmatic approach can help to understand how the language is arranged, as even mathematically exact, grammatical description is not apt to do it. M. Fludernik described the pragmatic approach in "The Fictions of Language and the Languages of Fiction" (Fludernik, 1993). According to the linguist, the relative "imperceptibility" of FID is its advantage in comparison with direct and indirect speech: the reader seldom consciously perceives it in the text as a special technique of rendering another person's speech. As a result, FID is usually used to achieve the effect of ambiguity or an inconspicuous change in perspective (Blinova, 2012).

In our research, we stick to the idea that FID is the third form of rendering another person's speech, occupying an intermediate position between direct and indirect speeches. As a rule, FID belongs to the level of the author, because like in indirect speech, all the pronouns and verbs, pertaining to it, are formally modelled from the author's point of view. Using FID, the author aims to preserve the lexical, phonetic and syntactic features of the internal and uttered speech of the characters, that is, FID belongs both to the level of the author and the level of the character.

The peculiarity of FID in Tsvetaeva's texts is the fact that the protagonist in the studied works is Marina herself, but in a different time and space, i.e., Marina as a child, Marina as a teenager or Marina as a woman. Therefore, we consider that the FID in the analysed texts is someone else's speech only for the purposes of discussion, as the narrator and the protagonist are in fact one and the same person. Since most part of the text is represented by thoughts and feelings, which are remote enough for the author, one can say that here we deal with special, Tsvetaeva's "masks": 1) a euphemistic mask; 2) an auto ironic mask; 3) a language-involving mask; 4) a transgender (character) mask (Voitekhovich \& Bykov, 2015).

Secondly, it is time and space that are the most significant substances in the poetry of this intellectual and philosophically profound author. She talks to time, argues with it; she now stops it, trying to run away from it and now gets in the center of the temporal field. For instance, M. Tsvetaeva boldly declares "Time, I bypass you!" In fact, an argument, a conflict with time, being turned towards it, with neglecting it, is one of the major traits of her entire oeuvre. M. Tsvetaeva connects the eternal basis of the world (Danilova, Razzhivin, \& Salimova, 2014). 


\section{Method}

Our study consisted of several stages: at first, precedent names from the texts were analyzed with the help of various dictionaries (philosophical, antique ones, etc.). The next step was selecting intertextual names within FID. Then followed their multilevel analysis: form the point of view of their origin, function, role, position in FID.

Our analysis of the "behavior" of personal names in the texts of Marina Tsvetaeva allowed us to make a number of interesting conclusions.

\subsection{The abundance and diversity of precedent names in Marina Tsvetaeva's texts}

The brightest feature in the poet's use of precedent names is their abundance and diversity (in chronological, thematic, genre and similar aspects), i.e. a proper name becomes one of the most important text-forming elements, regardless its position in the text and its functions: "Daniel" (1916), "Iosif" (1917) and many others. In this case, the precedent name itself and the word "name" become the center of the onomastic field.

In her famous poem "The Soul and the name", following the ancient Greek tradition, the poet emphasizes the mysterious connection of the human name and the individual's spirit and nature. But the God gave me another name: it's marine, marine... (translated by the author - Olga Puchinina)

The author doesn't only place the proper name to the foreground of the semantic field but "plays" upon this word. Thus, a proper name becomes the centre of the sound organization of the text, like an anagram. This traditional device with obvious allusions to Pushkin is demonstrated in the poem "Psyche" (1920). Punch and midnight. Punch - and Pushkin, // Punch - and a meerschaum pipe // Puffing.

The most saturated rhyme // Of the depth, the lowest tone. // So, before the blushed Shulamite stands // The gasping Solomon (More intensive than the organ and more ringing than the tambourine...).

The same device occurs in periphrasis (Ibragimov's cast-iron great-grandson), in metaphorical names (What is for you, young Derzhavin, the stranger with Beethoven's forehead).

By including elements of the language game into the text, the author emphasizes the conceptual significance of a person's name for her, for example in the poem "Phaedrus" (1923) we read the following: Hippolyte! Hippolyte! It hurts! // It sears ... The cheeks are flushed ... // What a cruel horror is hidden // In this name Hippolytus! This example illustrates a very interesting case of arranging FID - the "over-splashing" of the author's speech (in the form of direct address) and verbs (hurts, sears), which may be referred to both: the author and Hippolytus.

\subsection{The use of precedent names the purpose of analogy}

We found out that M. I. Tsvetaeva uses personal, religious and mythologic names not only to explicate the past, but also for the purpose of analogy, when the temporary layers of the past and the present merge in one whole in terms of perceiving reality, creating imperceptible transition of the author's words into direct speech.

But my mouth is tense and stern. // I'll die, - but won't betray my delight! // So Lord of Sabaoth of the heaven // Gave his ear to young David ("Marina! Thank you for the peace...", Easter Monday, 1918). The concept name, reflected in many different forms of the nouns (name), verbs (to name, to call), and adverbs (sonorously), acquires the so-called "black-and-white" colors.

O.G. Revzina writes, "In M. Tsvetaeva's poetic idiolect the use of proper names is closely correlated with the stages of its development" (Revzina, 1991). The perception of the proper name as a semantically full sign and its compliance with the referent develop in two directions; a) the name is found a "relevant", true symbol and is interpreted through associative signs, through the "story" of the mentioned personalities; cf.... Anna Akhmatova! This name is a great sigh. And it falls into the depth, that is nameless!; The child's name is Lev. The Mother's one is Anna. His name means wrath, his mother's name means peace ("Poems to Akhmatova" 1916); Dimitriy! Marina! In the world there is nothing more harmonious than your ... Fates! Names! (1916); also cf.: Elena. Achilles. Name a more accordant sound (from the cycle "Two" 1924); you may meet here characteristics of the name itself: Pushkin. Pushkin, Pushkin - a Noble name - as a vulgar abuse language - parrots ("Poems to Pushkin" 1931); cf. the poem, written in 1917: As if with your palm, you stroke the heart with your imperial name: August!; b) through various reasons a referent considers a proper name unacceptable, so he renames it: $O h$ why you were named Daniel? (from the cycle "Daniel" 1916). This "renaming" may go beyond a categorical class: Now you are called Marina - separation! ("I see you black-eyed - separation!" 1920); Shall I call you Hector or Bonaparte? Moscow or Troy? As a star and military map the City lay ... These examples are also FID, which don't essentially affect the form of the name itself: "The movement from a proper name to a referent's features is really effective, only when the form of denotation and its sound form are under consideration (see the 
examples above). The use of proper names in the secondary, characterizing function is of particular interest (Revzina, 1991).

In the stories "Hlystovki" and "The Devil", the writer uses biblical allusions to God, Blessed Virgin, and Christ. However, by some specific intention M. Tsvetaeva deliberately makes them anti-heroes, who possess not very pleasant qualities (slovenly appearance, for instance). Besides, she employs a derogatory and illiterate attribute "theirs" with reference to them.

But it were not they who came for apples, not those staid ones, but them, that is theirs Blessed Virgin and Christ, redheaded, skinny, with a forked beard and eyes - now I would say, in very ragged clothes and barefooted, theirs Christ - and theirs Blessed Virgin, old, no longer amber, but leather, and though not torn but still scary (Hlystovki, 1989).

\subsection{The use of proper names from Marina Tsvetaeva's immediate circle}

It stands to reason that one of the most frequently used proper names in Tsvetaeva's works are the names of the people from her immediate circle: Ariadne, Alya, Angelika. Besides, a great number of proper names are used in the form of dedication or direct address: to Anna Akhmatova, to Byron, to Balmont, to Bryusov, to Mayakovskiy, Poems to Pushkin, etc. The predominance of precedent names in comparison with her children's names allows us to conclude that Marina Ivanovna was a "spiritual poet", willing to consider the poetic reality to be the most important and authentic one, and the ordinary world to be secondary.

\subsection{The single use of precedent names in Tsvetaeva's poems}

The single use of precedent names in the poems is one more characteristic feature of the poet. She often uses them only in epigraphs, dedications or titles. She uses proper names (precedent or real ones) more than once very rarely, like for example in the poem "So - only Elena looks over the roofs" (1924).

\section{So - only Elena looks over the roofs of Troy!}

In this verse, consisting of six stanzas, the first four stanzas begin with the words "So - only Elena" (yet, the punctuation is not always identical), the fifth stanza begins with the words: "But no, not Elena!", and the final stanza runs as follows: As even Elena at the fine dinner // Didn't dare to look at her slaves...

\subsection{The ways of introducing proper names and personas into the text field}

Strangely enough, there are not very many ways of introducing proper names and personas. Among various author's artistic techniques, we find text introduction strategies to be of great importance, since it reveals the true scope of the language. N. V. Vasil'eva writes that "introducing a proper name is one of the major macrotextological issues, as it considerably determines further existence of a proper name in the text" (Vasil'eva, 2009). Writing a text, the author keeps it in mind that an addressee should be able to identify the message, thus a persona and his name are duly introduced, and sometimes a writer doesn't give a name to a persona. The author's intention implies elimination of any component of introductive combination, whereas different patterns of representing a persona and his name involve different variants of introduction.

We have analysed examples of anthroponomical introduction in Marina Tsvetaeva's texts, based on the classification by N. V. Vasil'eva (2009), and have concluded that the poet doesn't employ all the patterns to introduce a persona and a name, described in the special literature: 1 . A persona and a name are introduced simultaneously $(\mathrm{P}+\mathrm{N})$. 2. The author uses a name, but introduces and describes a persona later $(\mathrm{N} \longrightarrow \mathrm{P}) .3$. The author characterises an unnamed persona first and mentions his name further $(\mathrm{P} \rightarrow \mathrm{N})$. 4. The author gives a name without a persona $(\mathrm{N} \longrightarrow 0)$. 5. The author introduces an unnamed persona $(\mathrm{P} \longrightarrow 0)$.

For example, Tsvetaeva employs the method of introducing a persona by his/her name or surname, i.e. without a common noun or a pronoun before a proper name, to create the effect of involving the recipient into the text. For instance, in the poem "Two" (1923) we meet many example of this kind, though she never mentions to the reader whom she really means.

There are rhymes in this world // If you break them - they'll falter. // Homer, you were blind. // ... Siegfried and Brunhilde parted like this, // Having solved the nuptial deal with a sword.

Multi-level dedications and epigraphs are one of the features of Marina Tsvetaeva's poetic space and an introduction device, aimed at communicative lucidity.

When well-known names appear in the text, it doesn't require introductive explanation, as these names are commonly known (Vasil'eva, 2009). This device is used if the author intends to develop a persona's line in the text. However, some names can only be mentioned, i.e. a name does not become an active participant in the text. 
These are the names that are used in reference to someone else's speech. You go, just like me, // Your eyes are down. // I cast them down - too! // Passer-by, stop! (You go, just like me..., 1913)

The poet has several poems-dedications, entitled in the following way: "S.E.", "P.E." and others, and it will be difficult for a simple reader to understand to whom they are dedicated. Of course, for connoisseurs of Tsvetaeva's oeuvre these initials are evident; nevertheless, the author's desire to disguise the addressee, typical for the initial period of her creative work, is quite understandable.

Onomatologists rightly stress the consistency of "belonging a word to a proper name in the text, as the reader associates it with the other units that make up the "onomastic field" (Suprun, 2000) of the given language. One of the signs, pointing to this, is a capital letter. In some cases, a word may have different functions, i.e., a capital letter can neutralize some signs, leading to proprial personification: I am a lot of Poets...

The "proprialisation" of this kind may be illustrated by the following epigraph to a poem: ... It's the King Son's point - // To be great and good (1918).

\subsection{Precedent names in epigraphs and dedications}

Researchers notice that Tsvetaeva often uses epigraphs. Since she chooses them deliberately, it can be stated that epigraphs express the concept of the written work, become an integral part of the text and reflect the communicative intention of the author. It doesn't hold true to dedications, which play an important role in the onomastic space of Marina Tsvetaeva's poetry, as they are the names of real people (often the poet's contemporaries) or reflect her literary tastes. However, unlike epigraphs, they aren't always closely connected with the text itself.

Analyzing of works, preceded by dedications, we have revealed a certain pattern in the use of precedent names. It allowed us to single out a number of poems and on this basis we observe a new variant of onomastic introduction (for the purpose of discussion we call it "indirect" introduction), because the proper name is introduced into the text only through dedication, but is not met in the narration.

In the following examples through dedication, the author introduces a name, but doesn't introduce a persona. A number of names are met only in dedications (To Antokolskiy, To Vera Arenskaya, To Alexey Alexandrovich Podgaetskiy-Chabrov, To Boris Pasternak, To I. Ehrenburg), or in the title of the poem ("In Memory of Nina Javakha", "In Memory of Beranger", "To V.Y. Bryusov", To Jairus's daughter", "Daniel”, "George", "Marina", "Don Juan", "Carmen", etc., the cycle "Poems to Sonechka"). In these examples, precedent names in various variations (full name, pet name, first name + surname, name + patronymic + surname) are significant and require no further comments in the text.

The above-mentioned poem "To Anna Akhmatova" is almost of this kind, with one fundamental difference: the first name and the surname appear in the last lines of the poem "I fell in love with you, Anna Akhmatova". This feature is mirrored in the so-called "double" dedication: the poem "To the Generals of 1812" has the second dedication To Sergey.

There are also anthroponyms in epigraphs, or rather, an indication to the author of the famous lines, i.e. intertextual elements become precedent names:

"There is a certain hour ..."

Tyutchev.

Tsvetaeva cites the poem "Dream" by Tyutchev and uses it as an epigraph or a title to her own poem.

The poems from the cycle "Girlfriend" contain no anthroponyms. Whereas in the six-stanza poem "Clappers and neighbors' dogs sleep" (1915) a proper name is used in the end: The smell of a rose and the smell of a curl, // The rustle of silk around the knees ... // Oh, dear, - do you see, here she is - // Thwarter! - Carmen. (1915)

\subsection{Antique names in Tsvetaeva's anthroponymic corpus}

Antique names become an integral part of the anthroponymic corpus of Tsvetaeva's lines. "Eulogium on Aphrodite", "Hamlet's soliloquy with his conscience", the repeated line "Listen, listen, Adam" in the poem "Beware" (1922) and others confirm the fact that Tsvetaeva's poems are imbued with intertextual names. Rich spiritual and moral potential, accumulated over the centuries by different peoples, including literary, theatrical and musical experience of many generations, is revealed in Marina Tsvetaeva's texts in various forms (for example, How good it was to be at home with a book! // To the tunes of Grieg, Schumann and Cui // I learned the fates...). It testifies not only to the author's erudition, philological and linguistic background, but also to her involvement in the worldwide cultural macrospace. 
We will give only the names of such "antique" poems: "Psyche" (1918), "Sibyl and a youth" (1921), "Eulogium on Aphrodite" (1921), "Orpheus" (1921), "Amazons" (1921), "Sybil” (1922), "Phaedra" (1923), "Eurydice - to Orpheus" (1923), "Ariadne" (1923), "Naiad" (1928), etc. It means that the ancient world was an essential place of the poet's spiritual world. Even in the poem "Rails", in which the poet seems to talk not about certain people but about an endless stream of leaving people, there is a verse containing a precedent name. The hour, when despair as a matchmaker, // Spreads sheets out. - Yours! - // And voiceless Sappho is // Crying, the latest seamstress (1923).

Whether the poet uses the proper name of Sappho accidentally or just for the purpose of the rhyme is a matter for further research. But according to our observation, she doesn't make accidental use of proper names: for example, Sappho is an ancient Greek woman-poet from the island of Lesbos (the late $7^{\text {th }}-$ the early $6^{\text {th }}$ centuries B.C.), i.e. this verse also proves that Marina Tsvetaeva had a habit to interpret legends in her own way.

In the following untitled poem "Two - hotter than fur ..." a precedent name (anthroponym), typically for the poet, is placed in the last line: Even on the bed of disbelief you're gnawed // By the worm (how poor we are!). // The one to put the finger into Thomas's wound // Hasn't been born yet (7 January 1940). The name of Thomas is also symbolic: it's a reference to the biblical, phraseological background of people's memory.

In the essay "The House at Old Poemen", written after the death of her half-brother Andrey Ivanovich Tsvetaev (the son of her father, Ivan Vladimirovich, by his first wife, Varvara Ilovayskaya), Tsvetaeva writes about Dmitriy Ilovayskiy, his grandfather through his mother. In this essay, we find the following biblical allusions: Khronos, Charon, Sibyl, Lethe, Ganymede, Gill (Hercules's son), Proserpine, Atlantes, Elena, Susanna, Priam, Uranus, Hades and others. Tsvetaeva ironically calls Dmitriy Ivanovich Old Poemen, using a purely monastic name, which belonged to the Christian saint - Poemen the Great. Ilovaiskiy could hardly be called a monk or a saint, for he lived 88 years, was married twice and outlived almost all his children. The early death of her half-brothers and sisters at a young age seemed unfair to Marina. Therefore, the allusion to the Greek god of time Khronos (Zeus's father), devouring his children, or immortal Charon, who transported the dead through the river of oblivion, seems so expressive. Tsvetaeva writes: It was a house of death. Everything in the house came to an end, except death. Except old age. Everything: beauty, youth, charm, life. Everything in the house came to an end, except Ilovaiskiy (Tsvetaeva, 1989).

Nadezhda, the historian's daughter and a rare beauty, resembles Tsvetaeva of Helen of Troy or Susanna, a character from the Old Testament, whom some elderly men falsely accused of adultery: Beauty sleeping under the bespectacled - weak-sighted - farsighted - watery - and-God-knows-what-else! - eyes of the elders, Elena's elders, Susanna's elders, her father's seventy-year-old coevals (Tsvetaeva, 1989).

Literary allusions take a special place in Marina Tsvetaeva's texts. For example, we have found the titles of several literary works (for example, the fairy tale "Sleeping Beauty", the poem "Demons" by Alexander Pushkin, the ballad "Flying Ship" by Mikhail Lermontov, the poem "Night inspection" by Vasiliy Zhukovskiy, the poem "Dead souls" by Nikolay Gogol, the novel "Undine" by the German writer Friedrich Fouquet, the novel "Jane Eyre" by Charlotte Bronte, the novel "Anton The Unfortunate" by Dmitriy Grigorovich or "The Song of the Nibelungs"), or the names of literary characters (for example, Anna Karenina, The Forest King, Aleko, Zemfira) or word-for-word quoting of the text that indicate the classical literary orientation of the poet.

During our research, we have found out that Tsvetaeva frequently quotes Alexander Pushkin's works or characters. The poet was her first literary love and a source of inspiration throughout her literary career. For instance, in the story "The things that happened" she tells the story of her first love and compares herself to Tatyana Larina, the main character of the poem "Eugene Onegin". In the story "My Pushkin" Tsvetaeva confesses that she loves "Gypsies": Aleko and Zemfira, and that Mariula, and that gypsy, and the bear, and the grave, and the strange words, which this all is told with (Tsvetaeva, 1989). Before the upcoming trip to the sea, Marina Tsvetaeva used to recall Pushkin's poem "To the Sea": This was the apogee of inspiration. With "Farewell then, Sea..." my tears started. "Farewell then, Sea! I won't forget... (Tsvetaeva, 1989).

\section{Conclusion}

The use of intertextual (precedent) proper names is one of the features of the poet's individual style. During our research, we have studied 500 precedent names and their introduction into the text and we have found no cases of accidental use of the proper names. The only example of the so-called "accidental", not "speaking" names, which requires special consideration, is the poem "Poloterskaya (Floor polisher's)" (1924): Neither Stepan nor Osip // Leaves any sign or trace. // "We, floor polishers, always come out of time (inopportunely)."

The introduction of the name and the persona, especially within FID, explicates one of the major macrotextual 
tasks, as it determines the further existence of the name / or its absence in the text.

The anthroponymic analysis of Marina Tsvetaeva's texts shows that the author rarely uses persistent symbols, pointing to the professional identity (poet and writer), the state of kinship, and isolated symbols, reflecting different emotions; the studied groups represent an additional component in the characterization of the image. Being a person of wide reading, Marina Tsvetaeva automatically refers her readers to the well-known names, events, facts in the world history. Undoubtedly, it complicates the perception of her works for an unprepared reader. (We would like to quote our colleague, linguist, who was surprised at such a high general interest in Tsvetaeva's poetry and said, "It is impossible to read and understand her poems without philosophic, ancient reference books!") Some "juggling" with proper names has become one of style-forming features in the text-field of Marina Tsvetaeva's poems and prose. A variety of devices to introduce names and personas, used by the author, testifies to her skillful and phenomenal flexibility in the use of stylistic means and separate groups of words of the language. Anthroponymic patterns of introducing a name and a persona determine the further use of the name in the text, according to the author's intention, and promote a holistic understanding of Marina Tsvetaeva's individual world, which is unlikely to be fully understood by anyone. "I am a lot of Poets; and the way it's entwined in me is my secret," wrote Marina Tsvetaeva. The word "Poet" is written with a capital letter, therefore, it is used as a proper name; these words imply the answer, or rather, lack of response to the question, how Marina Tsvetaeva managed to write so, that you can neither comprehend nor explain it.

\section{Practical implications of the results}

The name of Marina Tsvetaeva has become a precedent name itself, as her works continue to attract the attention of young readers. Therefore, the results of our research can be used by students of philological departments, while taking such courses as Russian literature, Name in the text, Regional linguistics and others. We consider it important for students at school, undergraduate and postgraduate students to study the poet's works, and the issue in question in particular. For free indirect discourse, as the synergy of the author's thoughts and a persona's speech, through the prism of precedent names allows us to "feel" in a new way and to understand the great poet, whose work is generally recognized, but not entirely understood.

\section{References}

Bally, Ch. (1912). Le style indirect libre en français modern // Germanisch-Romanische Monatschrift, 4, 549-556.

Bakhtin, M. M. (1975). The problems of literature and aesthetics. Moscow: Khudozhestvennaya Literatura.

Blinova, O. A. (2012). Free indirect speech in English: the evolution of views in Western linguistics (1912-2012) // Bulletin of Novosibirsk State University. Series: Linguistics and Intercultural Communication, 10(2), 93-102.

Danilova, J. J., Razzhivin, A. I., Salimova, D. A. (2014). The temporal-spatial continuum in the texts of Marina Tsvetaeva and Zinaida Hippius // World Applied Sciences Journal, 31(2), 267-271. (ISSN 1818-4952). (C) IDOSI Publications, 2014 DOI: 10.5829/idosi.wasj.2014.31.02.14292.

Fludernik, M. (1993). The fictions of language and the languages of fiction. New York: Routledge, Retrieved from https://ru.scribd.com/document/75154385/the-Fictions-of-Language-and-the-Languages-of-Fiction.

Gorbanevskij, M. V. (1988). Onomastics in fiction: Philological studies. Moscow: UPF press.

Kalepky, T. (1913). Zum «Style indirect libre» («Verschleierte Rede») // Germanisch-Romanische Monatschrift, $5,608-619$.

Kusjko, E.Y. (1980). The language problems of the contemporary fiction. Represented speech in the literature of the GDR. Lvov: Vusshaya Schola.

Lerch, E. (1914). Die stilistische Bedeutung des Imperfektums der Rede «style indirect libre» // Germanisch-Romanische Monatschrift, 6, 470-489.

Revzina, O. G. (1991). Proper names in M. Tsvetaeva's poetic idiolect // Poetics and stylistics. 1988-1990 / edited by Grigor'ev V. P. Moscow: Nauka, 172-192. Retrieved from http://danefae.org/lib/ogrevzina/sobst.htm.

Salimova, D. A., Danilova, Yu. Yu. (2009). Space and time as categories of the text: theory and experience of research. Moscow: Flinta: Nauka.

Suprun, V. I. (2000). Onomastic field of the Russian language and its artistic and aesthetic potential: Monograph. Volgograd: Peremena. 
Tobler, A. (1887). Vermischte Beitrage zur französischen Grammatik // Zeitschrift fur romanische Philologie, 11, 67-74.

Tsvetaeva, Marina (1990). The leaves have crumbled over your grave... Kazan: Tatarskoe knizhnoe izdatel'stvo.

Tsvetaeva, M. I. (1989). Prose. Moscow: Sovremennik.

Vasil'eva, N. V. (2009). The proper name in the world of text. Moscow: Knizhnyj dom "Librokom".

Voitekhovich, R. S., Bykov, A. V. (2015). Types of masks in Marina Tsvetaeva's poetry // European Journal of Science and Theology, 11(5), 119-128.

\section{Copyrights}

Copyright for this article is retained by the author(s), with first publication rights granted to the journal.

This is an open-access article distributed under the terms and conditions of the Creative Commons Attribution license (http://creativecommons.org/licenses/by/4.0/). 